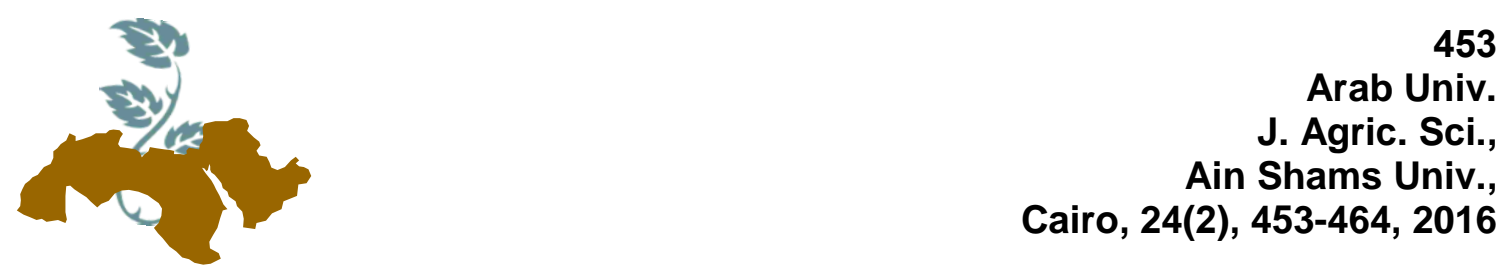

\title{
WILLINGNESS OF EGYPTIAN AGRICULTURAL EXTENSION MIDDLE LEVEL MANAGERS TO USE CELL PHONES IN EXTENSION SERVICES
}

Diab1, A.M. and Zeinab M. Abdel-Rahman ${ }^{2}$
1- Rural Sociology \& Agricultural Extension Department, Faculty of Agriculture, Assiut University, The New Valley Branch, Egypt

2- Rural Sociology \& Agricultural Extension Department, Faculty of Agriculture, Ain Shams University, Cairo, Egypt

*Corresponding author, email: a.diab@aun.edu.eg

zmahmoud33@yahoo.com

Keywords: willingness to change, miso-level managers, DINAMO scale, change-related behavior, Egypt

\section{ABSTRACT}

The purposes of this study are to: i) assess the agricultural extension middle level managers' willingness to use cell phones in extension services, and ii) investigate the factors affecting their willingness to change and their change- related behavior. The DINAMO scale developed by Metselaar (1997) was used to assess their willingness to use cell phones in extension. Data were collected from 19 agricultural extension middle level managers representing $67.86 \%$ of the total number of middle level managers (28 mid-managers) by questionnaire during their annual meeting that was held on May 2015. Mean scores, percentages, and Chisquare test were used for data presentation and analysis. The results showed that the respondents' overall willingness to change is 220.2 which represents $72.2 \%$ of the total score; this implies that extension middle level managers are entirely have positive willingness to use cell phones in agricultural extension services. There are seven variables have significant relationships with extension middle managers' willingness to change namely: Managers' affective orientation towards the use cell phones in extension $\left(x^{2}=38\right)$, The value of use cell phones for the agricultural extension organization $\left(\mathrm{x}^{2}=37.07\right)$, Collegial attitudes towards use cell phones in extension ( $x^{2}=38.22$ ), Self-control factors $\left(x^{2}=38\right)$, External control factors $\left(x^{2}=36.24\right)$,
Control over and contentment with use cell phones in extension $\left(x^{2}=24.7\right)$, and Perceived complexity of use cell phones in extension $\left(x^{2}=31.16\right)$. On the other hand there are five variables affecting the change- related behavior of the middle managers as follows: Managers' affective orientation towards the use cell phones in extension $\left(x^{2}=51.19\right)$, Collegial attitudes towards use cell phones in extension $\left(x^{2}=51.12\right)$, External control factors $\left(x^{2}=50.34\right)$, Control over and contentment with use cell phones in extension $\left(x^{2}=25.82\right)$, and The middle manager's willingness to use cell phones in extension $\left(x^{2}=24.61\right)$. It could be concluded that there is a strong opportunity for using cell phones in extension services, and the respondents are ready for the beginning of such initiative.

\section{INTRODUCTION}

Agriculture is becoming a progressively a knowledge-intensive endeavor. The contribution of agriculture to national economic growth relies on its aggregate factor productivity. Further, the productivity of the agricultural sector relies in-turn on how farmers can effectively and efficiently increase their production through utilization of the ideal consolidation of inputs, the know-how, and territory management techniques. Yet, the existing levels of knowledge and information on how to produce, process, and market commodities stay at the threshold for extensive numbers of smallholder farmers. This is partly due to the quality and quantity of extension and advisory services that is available to the farmers from different sources. Developing countries, in their quest for improving for- 
ward their entry to knowledge for all farmers, have embarked on a series of reforms that have resulted in a wide range of outcomes (Babu, \& Joshi, 2015: 25).

A significant number of organizations, i.e. agricultural extension organization, have been actualizing change, the pace, magnitude and importance of which have expanded extensively in recent years. Such transforms would frequently focused at moving forward the viability of the associations so that they generate value, having a basic goal of empowering an organization and its functions cope with a challenging environment (Blackman, et al 2013: 2). ICT might aggravate the best commitment by telescoping distances and lessening the cosset of interaction between stakeholders. It has the potential to help farmers in the entire cycle of production, i.e., starting with production and ending with sales. Most efforts to make ICT accessible to rural farmers have sought to improve the availability and quality of information either indirectly through producer associations, extension workers and the like, or directly through broadcast radio information, call centers, and mobile short messaging services (SMS) (Mittal, et al 2010: 4).

The expanding infiltration of mobile networks and handsets presents a chance to make suitable information more generally accessible. This might assist agricultural markets to operate more successfully, and overcome some of the other challenges faced by the sector (Mittal, et al 2010: 2). Cell telephone infiltration in the developing world currently exceeds two subscriptions for every three people, driven by expanding networks in Asia and in Africa. The capacity to purchase a low-cost mobile phone is complemented by the expansion in telecommunications infrastructure; most countries now have more than 90 percent of their population served by a cell phone signal, including coverage in rural areas (The World Bank, 2011: 5). In Egypt, mobile subscription reached 93.24 million subscriptions during July -September 2015 (Ministry of Communications and Information Technology, 2015: 2).

Agricultural extension systems over practically less developed nations are under-funded and have had mixed effects like the defect of employees/farmers proportion. A great deal of the extension information has been found to be out of date, irrelevant and not applicable to small farmers' demands, leaving such farmers with very little information or resources to improve their productivity (Meera et al 2004: 1). Mobile phone access has the chance to assist extension employees for de- livering services to various small and marginal farmers (Cole and Fernando, 2012: 8).

In June 2011, a pioneering initiative to utilizing the cell phones in Egyptian Agricultural Extension was announced by a collaboration protocol among the Ministry of Agriculture and Land Reclamation, Vodafone Egypt and Quick Serve Company. The project is planned to provide farmers with agricultural news and information using SMS, in addition to contacting with the specialists in the Agricultural Research Center (ARC) through direct calls, SMS and voice messages (Central Administration for Agricultural Extension, 2011, Abdel-Gany, 2014: 1). The Protocol avails agricultural extension services via cell phones starting from cultivation to harvesting as well as providing the framework for launching a call center for Egyptian farmers. The Center will provide specialized guidance to Egyptian farmers through the ARC, in cooperation with Quick Serve Company (Vodafone Egypt, 2011).

Although, the services of the above mentioned protocol of collaboration have not been activated yet, the protocol in itself shows it clear that "cell phone extension represents a possibility change in the way Egyptian agricultural extension provides its services" (Abdel-Gany, 2014: 1). A significant number of factors contribute to the effectiveness with which such organizational changes are implemented. Important among those factors is "willingness to change". Willingness to change is containing people's beliefs and intentions regarding the extent to which changes are required and their perception of individual and organizational capability to successfully make those changes (Bouckenooghe \& Devos, 2007: 5). It is the cognitive forerunner to the behaviors of either imperviousness to, or support for, a change effort. Willingness may be reflected in the organization members' beliefs, attitudes, furthermore intentions regarding the extent to which changes would be needed and the organization's capacity to successfully make those changes (Susanto, 2008: 50).

As stated by Thomas and Dunkerley (1999), it is often the role of the middle level manager to formulate and enable the application of the change. Here, middle level managers' position in change processes turned unique, since they both understand the top managements' desire for direction of the strategy, as well as the employees, since they are in close contact with them. Hence, the middle managers act as change agents between top management and employees (Bäckvall \& Englund, 2007: 2). 


\section{Willingness of Egyptian Agricultural Extension Middle Level Managers to Use Cell Phones in Extension Services}

From this starting point, the purposes of this study are to: i) assess the agricultural extension middle level managers' willingness to use cell phones in extension services, and ii) investigate the factors affecting their willingness to change and their change- related behavior.

\section{REVIEW OF LITERATURE}

\subsection{Mobile agricultural extension}

Agricultural extension services include transmitting knowledge to farmers, advising and educating farmers in their decision making, empowering farmers to elucidate their own objectives and potentials, and motivating desirable agricultural developments. Traditional public-sector extension services uses a variability of extension programs to overcome barriers to technological adoption without much success (Fu \& Akter, ND: 5). The literature surveyed highlights the quick growth of portable telephony in the emerging developing countries of Asia and Africa and their key role in decreasing information search costs, information asymmetries and expanding market efficiencies. The utilization of cell telephones has been found to inspire poor farmers of these countries towards greater market participation and diversification to high-value crops. This has helped enlarge their profit through higher price realization and lessening in wastages (Mittal, et al 2010: 4).

Mobile phones have numerous key advantages including: i) they are owned by more people, ii) they are provide provision in an instant, more suitable way, iii) they can convey personalized information to individual owners, iv) they are inexpensive to provide other functions such as voice communication, $v$ ) they decrease the charge of information and communication, vi) they empower both audio and video functions which can meet most of the essential necessities of the poor, vii) they have greater affordability than the internet and they also offer prospects to access new sources of information (Fu and Akter, 2011: 3, Fielding and Ninsiima, 2012: 1).

Today, mobile-enabled agricultural services act as tools to deliver extension services through infrastructure for mobile telephony and help generate consciousness amongst farmers (Mittal, et al 2010: 3). Mobile phones are being utilized to help raise farmers' incomes, making agricultural marketing more efficient, bringing down information costs, decrease transport costs, afford a platform to deliver services and innovations, increase access to information via agricultural extension services, increment of communication linkages with research systems, and upsurge access to public and private information sources (The World Bank, 2011: 52; Aker, 2011: 8). Versatile telephones might enhance access to and utilization of information which helps a farmer with fundamental information such as what to plant and which seed varieties to use (know-how information); the contextual information such as weather, plant protection, best practice for cultivation and inputs; and market information such as prices, and demand indicators (Mittal et al 2010: 13).

\subsection{Middle managers and agricultural exten- sion}

Floyd and Wooldridge (1994) define middle management and the middle managers as the facilitator between daily activities of the units and the strategic activities of the hierarchy; they stress the middle manager's role as a link, a tie between top managers and operational employees (Kuyvenhoven \& Buss, 2011: 3). The middle managers have been a target for criticism in the change process, and regularly get faulted as being obstructive and resistant. The manager introducing the change often becomes hated by the ones negatively affected by the change. Nevertheless, the middle managers' achievement in the change implementation process largely has an impact on the consequence of the change. Therefore, middle managers' contributions in organizational changes can meaningfully influence whether or not it becomes successfully applied (Bäckvall \& Englund, 2007: 2-3).

Middle managers are instrumental to improving overall engagement and corporate performance. They are able to see the vision at the highest priority of the organization and the grievance at the bottom. The organization of the future, however, will oblige this assembly to be strong, effective, and willing (Caye, et al 2010: 1). Middle level managers play a critical role in the extreme capacity of the organization to accomplish its strategic goals. The most successful middle managers must rely on strong influencing skills and the ability to organize a complex network of resources to get results (McKinney, et al 2013: 1). On one hand they transform organizational goals and strategy into real actions, and on the other, they convert autonomous managerial action into strategic intent. Middle managers are seen as vital to translate entrepreneurial initiatives developed at the front into organizational outcomes. They actively endorse ideas, construct support, overcome re- 
sistance, and guarantee that the innovative ideas are implemented and monitored (Mair, 2002: 2).

Agricultural Extension Organization in Egypt is one of seven sectors consisting the organizational structure of the Ministry of Agriculture and Land Reclamation (MALR). The Ag Ex. Sector includes four main central administrations; one of them is the Central Administration for Agricultural Extension (CAAE). The extension organization is represented at all administrative levels, starting from the central level in Cairo (represented by the CAAE), to the Directorates of Agriculture at governorate levels to District levels, down to the Village level (El-Shafie, 2009: 46; Abdel-Ghany \& Diab, 2013: 148).

\subsection{Willingness to organizational change}

Due to the progressively dynamic environments, organizations would continually confronted with the necessity to implement changes in strategy, structure, process, as well as culture. Organizational change in government organizations over the past two decades has been dominated by New Public Management (NPM) initiatives directed towards transforming these organizations from bureaucratic to market-oriented and efficient entities, although retaining public responsibility (Ryan, 2008: 1).

According to Greenberg and Baron (2002), the organizational change alludes to planned or unplanned transformations in the structure, technology and/ or people of an organization; also as stated by Del Val and Fuentes (2003), it is variations in shape, quality, or state over time after an introduction of new ways of working, thinking, and acting within an organization (Vos, 2006: 6). It is a top-down process applied by change agents and managers (Petrou \& Demerouti, 2015: 470), or it is a planning and actions to alter collective behavior in the pursuit of particular objectives (Helfrich et al 2011: 2).

In order to improve the probability of change success, the literature points to a range of theories used to explain the processes and elements of change as follows (Blackman, et al 2013: 2): 1) life-cycle models looking at change as a series of ongoing changes; 2) teleological models considering change towards a planned goal or end state; 3 ) dialectical theory which assumes that change occurs when disparate values, forces or events gain sufficient power to challenge status; 4) evolutionary models which argue change is a recurrent, cumulative and probabilistic progression of variation, selection and retention of organizational enti- ties. In these models a regular factor cited as needed to overcome the potential for failure is the need for all those involved to have 'bought in' to the process, especially as there is a widespread assumption that individuals resist change and that leaders do not prepare the organization precisely sufficient.

Drawing on Lewin's three-stage model of change, Unfreeze - Change - Refreeze, whereby the organization prepares for the change, then makes the change and then adopts it as a continuing state. The successful change occurs where the leadership understands that the change process is a series of phases needing time; a process similar to the concept of "unfreezing", including phases such as building momentum, warm-up or defrosting activities, or gaining buy-in to the change exertion (Weiner, 2009: 2).

Disappointments of organizational change application can be attributed to the organization's powerlessness to provide for an effective unfreezing process before trying the change. Three overlapping phases are suggested: "readiness or willingness" where organizational members are willing for the change, "adoption" which is the period where the change is still on trial, and "institutionalization" which involves efforts to adopt the changes (Blackman, et al 2013: 2). The fruitful change efforts are characterized by many organizational factors, including employee and manager attitudes towards change (to what degree it is possible and desirable); leadership support (making the change a priority); slack resources; adequate planning (clarity of goals and roles); and mechanisms for tracking and reporting progress. Some organizational scholars propose that these factors are generally observable at the outset of a change initiative, and taken collectively, constitute an organization's willingness to make the change. If accurately assessed, baseline organizational willingness could be used to foresee the probability of successful change or diagnostically for formative evaluation (Helfrich et al 2011: 2).

Organizational willingness to change is considered a critical forerunner to the successful application of complex. Indeed, some suggest that failure to establish sufficient willingness accounts for onehalf of all unsuccessful, large-scale organizational change efforts (Weiner, 2009: 2).

By assessing willingness to change, change agents, managers, human resource management professionals, and organizational development consultants can recognize gaps that may occur between their own prospects about the change 


\section{Willingness of Egyptian Agricultural Extension Middle Level Managers to Use Cell Phones in Extension Services}

effort and those of other organizational members. If noteworthy gaps are founded and no action taken to close those gaps, resistance would be expected and change application would be threatened. In essence then, assessment of an organization's willingness to change can serve as a guide as a strategy for applying organizational changes may be created (Holt et al 2007: 290).

With regard to planned change processes, managers' actual control over their behavior strongly depends on the degree to which the change is imposed upon them. Still, the quantity of willingness to change can vary considerably from manager to manager, resulting in behaviors that support or hinder ongoing change. It should be clear that no single manager is responsible for the failure or success of an entire change process. Successful change is always the result of a combined effort by all organization members. Furthermore, many variables which influence ongoing change are outside the manager's control. (Metselaar, 1997: 48-49).

Metselaar (1997: 56-64) presented the Willingness to Change (DINAMO) scale as a tool can be used to assess middle managers' willingness to organizational change; and identified the critical ten dimensions (70 items) of willingness to change of middle managers by addressing the different facets of willingness to change. The scales formed ten homogeneous clusters around the five central elements of Ajzen's model: A) attitude, B) subjective norms, C) perceived behavior control, D) intention and E) behavior (Table 1).

Table 1. Overview of the ten dimensions of the DINAMO scale

\begin{tabular}{|c|c|c|}
\hline Elements & Scales of the DINAMO & $\begin{array}{l}\text { No of } \\
\text { items }\end{array}$ \\
\hline \multirow[t]{3}{*}{ Attitude } & $\begin{array}{l}\text { 1. Consequences of the } \\
\text { change for the middle man- } \\
\text { ager's work }\end{array}$ & 9 \\
\hline & $\begin{array}{l}\text { 2. Managers' affective orien- } \\
\text { tation towards the change }\end{array}$ & 5 \\
\hline & $\begin{array}{l}\text { 3. The value of the change } \\
\text { for the organization }\end{array}$ & 4 \\
\hline $\begin{array}{l}\text { Subjective } \\
\text { Norm }\end{array}$ & $\begin{array}{l}\text { 4. Collegial attitudes towards } \\
\text { the change }\end{array}$ & 6 \\
\hline \multirow[t]{4}{*}{$\begin{array}{c}\text { Behavioral } \\
\text { Control }\end{array}$} & 5. Self-control factors & 8 \\
\hline & 6. $\quad$ External control factors & 12 \\
\hline & $\begin{array}{l}\text { 7. Control over and content- } \\
\text { ment with the change process }\end{array}$ & 7 \\
\hline & $\begin{array}{l}\text { 8. Perceived complexity of } \\
\text { the change }\end{array}$ & 7 \\
\hline Intention & $\begin{array}{l}\text { 9. The middle manager's } \\
\text { willingness to change }\end{array}$ & 4 \\
\hline Behavior & $\begin{array}{l}\text { 10. Overt manifestations of } \\
\text { willingness or resistance to } \\
\text { change }\end{array}$ & 8 \\
\hline
\end{tabular}

\section{METHODOLOGY}

The current study used the DINAMO scale to assess extension middle managers' willingness to use cell phones in extension services. Out of the total 70 items of the DINAMO, 67 were used for assessing the respondents' willingness to use cell phones. The remaining three items were considered not applicable to the study (two of them were to "self-control factors component" and the third one was belonging to the "Collegial attitudes towards the change component").

A questionnaire form on the DINAMO scale was composed and distributed among the attendees of the annual meeting of the general managers of extension administration at governorate level (middle managers of extension) which was held during May 2015. The completion of the questionnaires was followed up thereafter and the completed forms were personally collected. The total number of returned completed forms was 19 representing $67.86 \%$ of the total number of extension middle managers (28 mid-managers) at the national level. With regard to statistical analysis, mean scores, percentages, and Chi square test were used for data presentation and analysis.

The respondents were asked to respond on a 5-point Likert-type scale ranging from 1 (strongly disagree) to 5 (strongly agree) to the statements of the dimensions of DINAMO scale except the last dimension "Overt manifestations of willingness or resistance to change" which consists of eight behavior statements. Respondents' responses were marked as 'applies or does not apply ' scores of 1 or 0 were assigned to the statement. In addition, the values 4 to -4 were assigned to the behavior dimension bl to b8, respectively. Subsequently, a measure of manager behavior was computed using the statistics:

Behavior $=\left(b 1^{*} 4\right)+\left(b 2^{\star} 3\right)+\left(b 3^{\star} 2\right)+\left(b 4^{*} 1\right)-\left(b 5^{*} 1\right)-\left(b 6^{*} 2\right)-\left(b 7^{\star} 3\right)$ $-\left(b 8^{*} 4\right)$

In order to achieve the second objective of the study, seventeen hypotheses could be formulated as follows:

The degree of middle level managers' willingness to change (use cell phones in extension services) and their change- related behavior are positively related to: the degree to which middle managers expect positive consequences of the organizational change on their work $\underline{(\mathrm{H} 1)}$ and $(\mathrm{H} 2)$; the more managers hold a positive affective orientation towards an organizational change $(\mathrm{H} 3)$ and $(\mathrm{H} 4)$; the more middle managers perceive the value of the change $\underline{(\mathrm{H} 5)}$ and $\underline{\mathrm{H} 6)}$; The more middle man- 
agers perceive the positive collegial attitudes towards the change, $(\mathrm{H} 7)$ and $(\mathrm{H} 8)$; The more experience and knowledge of the control of change processes middle managers have at their disposal $\underline{(\mathrm{H} 9)}$ and $(\mathrm{H} 10)$; the more resources to control change process (time, money, information) middle managers have at their disposal $(\mathrm{H} 11)$ and $(\mathrm{H} 12)$; the more the middle managers perceive the process rate as adequate $\underline{(\mathrm{H} 13)}$ and $\underline{(\mathrm{H} 14)}$; the more middle managers perceive a change as low complex $(\mathrm{H} 15)$ and $(\mathrm{H} 16)$.

The greater middle managers' willingness to use cell phones in extension services, the more will they actively support the change process $\underline{(\mathrm{H} 17)}$.

\section{RESULTS AND DISCUSSION}

\subsection{Personal characteristics of extension mid- dle managers}

Table 2 indicates the distribution of extension middle managers according to their personal characteristics; it became clear that most of respondents were aged 50 years or more, have rural origin, and have more than 10 years of work experience in agricultural extension.

Table 2. Distribution of extension middle managers according to their personal characteristics $(\mathrm{N}=19)$

\begin{tabular}{|c|c|c|}
\hline Characteristics & Category & Frequency \\
\hline \multirow{2}{*}{ Age } & Below 50 years & 7 \\
\cline { 2 - 3 } & 50 and above & 12 \\
\hline \multirow{2}{*}{ Origin } & Rural & 18 \\
\cline { 2 - 3 } Work experience & Urban & 1 \\
\cline { 2 - 3 } in extension & $\begin{array}{c}\text { years than 10 } \\
\text { 10 years and } \\
\text { above }\end{array}$ & 2 \\
\hline
\end{tabular}

Source: the study's findings.

\subsection{Extension middle managers' perception of the components of the DINAMO scale}

Table 3 shows mean scores and percentages for extension middle managers' perception of the willingness to change (DINAMO) scale statements. It can be realized that the respondents' overall willingness to use cell phones in extension services is 220.2 which represents $72.2 \%$ of the total score; this implies that extension middle level managers are entirely have positive willingness to use cell phones in extension services. The table also revealed that scores are above overall average levels for six components of the DINAMO scale while the remaining four components are less the overall average scores.

The table revealed also that "Managers' affective orientation towards use cell phones in extension" received the highest score among the ten components ( $85 \%$ of the maximum score) followed by the component "middle managers' willingness to use cell phones in extension" $(79.5 \%$ of the maximum score); this implies that cell phone utility in extension services has gained the middle level manager' advocacy which could be reflected in its potential success. On the other hand the component "overt manifestations of willingness or resistance to use cell phones in extension" received the lowest score (24.2\% of the maximum score) followed by the component "Control over and contentment with use cell phones in extension" (62.9\% of the maximum score); this indicates that the low satisfaction of the middle managers on the strategy used with the change (use cell phones in extension services) may affect their overt manifestations of willingness or resistance to the change.

The Radar Chart as shown in Figure 1 was used to illustrate the gap between maximum and mean scores of extension middle managers' perceptions of the DINAMO scale components; this gap could be calculated by subtracting the mean scores from the maximum ones. The Figure also revealed that the component "Managers' affective orientation towards the use cell phones in extension" showed the lowest gap with value (3.74), followed by "The middle manager's willingness to use cell phones in extension" component (4.11); while the component "External control factors" received the highest gap with value (15.68), followed by component "Consequences of use cell phones in extension for the middle level manager's work" (13.89), then component "Control over and contentment with use cell phones in extension" (13.00). 
Table 3. Means and percentages of extension middle managers' perceptions of the DINAMO scale dimensions

\begin{tabular}{|c|c|c|c|c|c|}
\hline No & components of the DINAMO scale & $\begin{array}{l}\text { Max. } \\
\text { score }\end{array}$ & $\begin{array}{l}\text { Mean } \\
\text { score }\end{array}$ & $\%$ & $\begin{array}{l}\text { Gap } \\
\text { score }\end{array}$ \\
\hline 1 & $\begin{array}{l}\text { Consequences of use cell phones in extension for the middle } \\
\text { level manager's work }\end{array}$ & 45 & 31.11 & 69.13 & 13.89 \\
\hline 2 & $\begin{array}{l}\text { Managers' affective orientation towards the use cell phones in } \\
\text { extension }\end{array}$ & 25 & 21.26 & 85.04 & 3.74 \\
\hline 3 & $\begin{array}{l}\text { The value of use cell phones for the agricultural extension } \\
\text { organization }\end{array}$ & 20 & 13.95 & 69.75 & 6.05 \\
\hline 4 & Collegial attitudes towards use cell phones in extension & 25 & 18.47 & 73.88 & 6.53 \\
\hline 5 & Self-control factors & 30 & 23.53 & 78.43 & 6.47 \\
\hline 6 & External control factors & 60 & 44.32 & 73.87 & 15.68 \\
\hline 7 & $\begin{array}{l}\text { Control over and contentment with use cell phones in exten- } \\
\text { sion }\end{array}$ & 35 & 22.00 & 62.86 & 13.00 \\
\hline 8 & Perceived complexity of use cell phones in extension & 35 & 27.26 & 77.89 & 7.74 \\
\hline 9 & $\begin{array}{l}\text { The middle manager's willingness to use cell phones in exten- } \\
\text { sion }\end{array}$ & 20 & 15.89 & 79.45 & 4.11 \\
\hline 10 & $\begin{array}{l}\text { Overt manifestations of willingness or resistance to use cell } \\
\text { phones in extension }\end{array}$ & 10 & 2.42 & 24.20 & 7.58 \\
\hline & Overall total of willingness to use cell phones in extension & 305 & 220.2 & 72.2 & 84.8 \\
\hline
\end{tabular}

Source: the study's findings. " gap score = maximum score - mean score

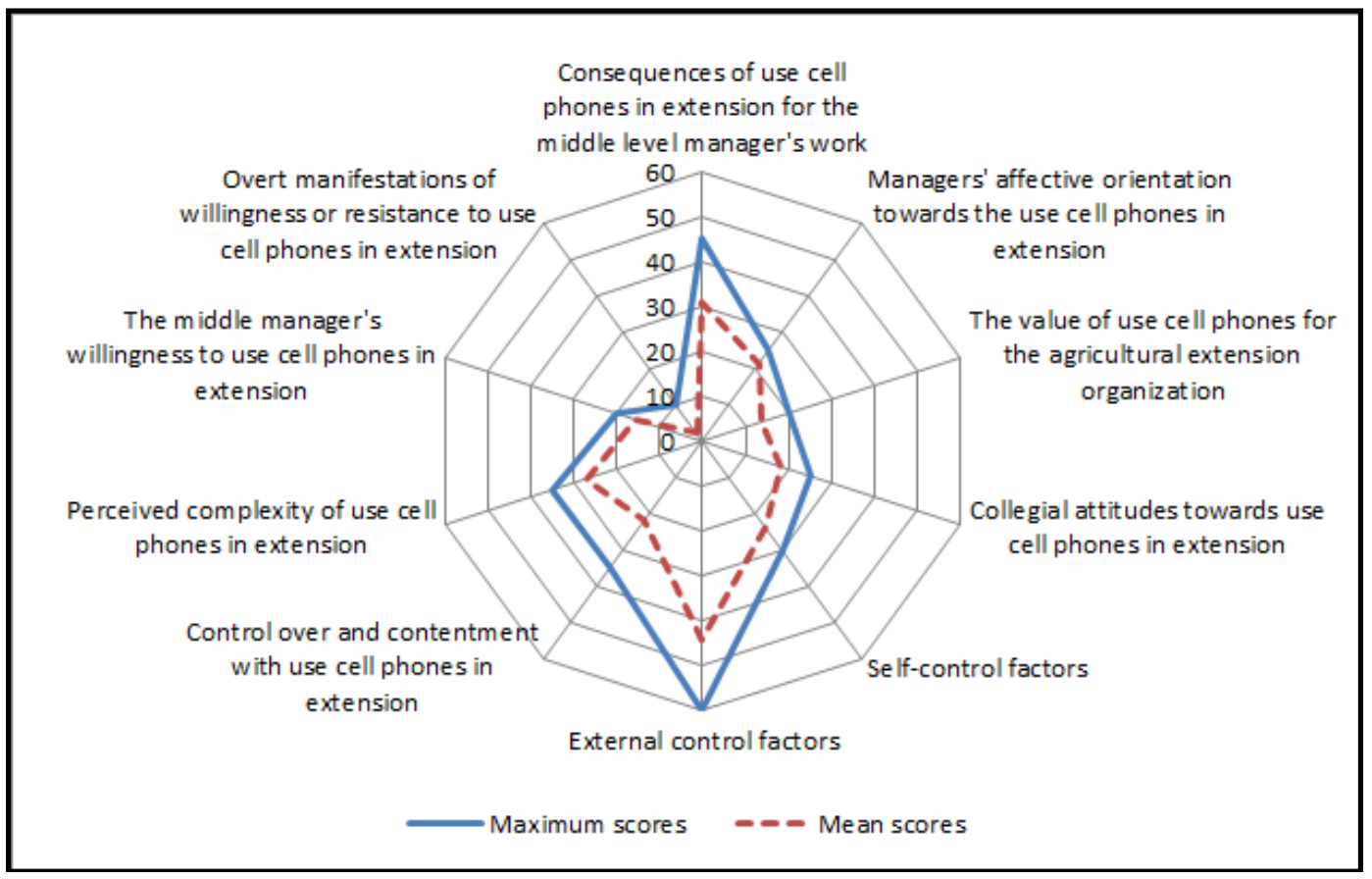

Figure 1. Radar Chart displays of gap between maximum and mean scores of extension middle managers' perceptions of the DINAMO scale components Source: the study's findings. 
4.3. Factors affecting extension middle level managers' willingness to use cell phones in extension services and their change- related behavior

With regard to factors affecting the willingness to change, Chie-square was used to test the relationships between the willingness of middle level managers to use cell phones in agricultural extension services and their change- related behavior. Results in Table 4 and Figure 2 show that seven of the eight variables have a significant relationships at 0.01 level of significance with extension middle level managers' willingness to use cell phones in extension, while the remaining variable "Consequences of use cell phones in extension for the middle level manager's work" has no effect on their willingness to its utility.

On the other hand there are five variables affecting the change- related behavior of the middle level managers, three of them have significant relationships at 0.05 , they are "Collegial attitudes towards use cell phones in extension" (Chiesquare $=51.12)$, "Control over and contentment with use cell phones in extension" (Chie-square = 25.82), and "The middle manager's willingness to use cell phones in extension" (Chie-square = 24.61). The remaining two, "Managers' affective orientation towards the use cell phones in extension" and "External control factors" were significantly affected middle managers' cell phone- related behavior at 0.01 level of significant with Chiesquare values of 51.19 and 50.34 , respectively.

Finding revealed also that all of research alternative-hypotheses could be (research nullhypotheses could not be) accepted except the hypotheses no. $\mathrm{H} 1, \mathrm{H} 2, \mathrm{H} 6, \mathrm{H} 10$, and $\mathrm{H} 16$. This implies that managers' willingness to use cell phones in extension services was not related with the degree to which middle managers expect positive consequences of the organizational change on their work. While their change- related behavior was not related with their perception the value of the change to their organization, experience and knowledge of the control over and contentment of change processes they have, and the perceived complexity of the change (use cell phones in extension services).

Table 4. Chi-Square values of the studied variables with willingness to change and change-related behavior

\begin{tabular}{|c|l|c|c|}
\hline No & \multicolumn{1}{|c|}{ Variables } & $\begin{array}{c}\text { willingness to change } \\
\text { (use cell phones in } \\
\text { extension services) }\end{array}$ & $\begin{array}{c}\text { Change- } \\
\text { related } \\
\text { behavior }\end{array}$ \\
\hline 1 & $\begin{array}{l}\text { Consequences of use cell phones in extension for the } \\
\text { middle level manager's work }\end{array}$ & 12.09 & 22.93 \\
\hline 2 & $\begin{array}{l}\text { Managers' affective orientation towards the use cell } \\
\text { phones in extension }\end{array}$ & $38.00^{* *}$ & $51.19^{* *}$ \\
\hline 3 & $\begin{array}{l}\text { The value of use cell phones for the agricultural exten- } \\
\text { sion organization }\end{array}$ & $37.07^{* *}$ & 26.54 \\
\hline 4 & Collegial attitudes towards use cell phones in extension & $38.22^{* *}$ & $51.12^{*}$ \\
\hline 5 & Self-control factors & $38.00^{* *}$ & 37.57 \\
\hline 6 & External control factors & $36.24^{* *}$ & $50.34^{* *}$ \\
\hline 7 & Control over and contentment with use cell phones in & $24.70^{* *}$ & $25.82^{*}$ \\
\hline 8 & Perceived complexity of use cell phones in extension & $31.16^{* *}$ & 18.91 \\
\hline 9 & $\begin{array}{l}\text { The middle manager's willingness to use cell phones in } \\
\text { extension }\end{array}$ & - & $24.61^{*}$ \\
\hline
\end{tabular}

Source: the study's findings. * Significant at 0.05 level ** Significant at 0.01 level 


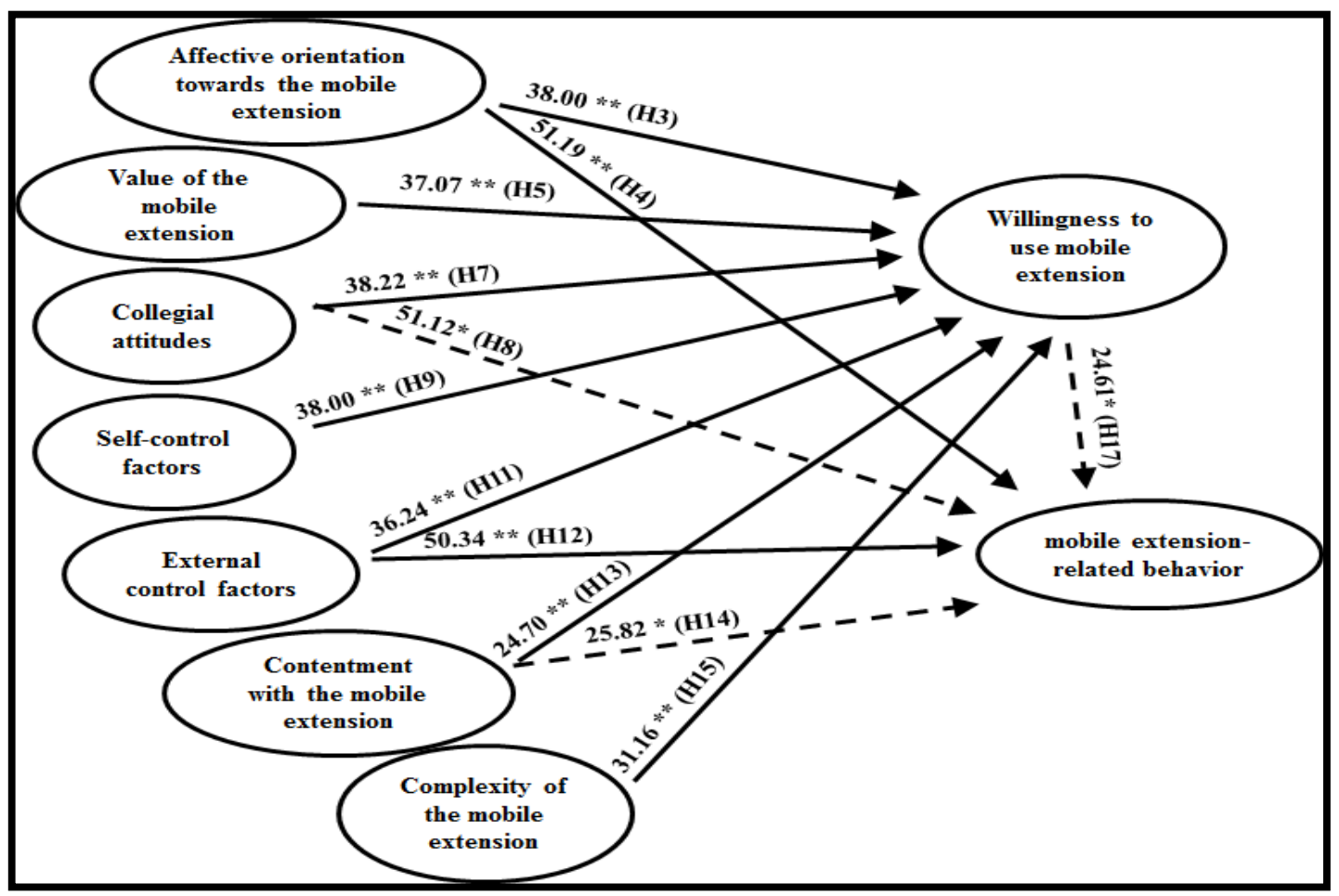

Figure 2. Factors affecting extension middle level managers' willingness to change and their changerelated behavior

Source: the study's findings.

\section{CONCLUSION}

This study highlighted the significance of recognizing middle level managers' willingness to change before any change initiative to take place inside agricultural extension organization in Egypt. The results of the middle managers' willingness to change (DINAMO) scale showed a high opportunity for the proposed change (use cell phones in extension services), and the respondents are ready to start this change. It could be concluded that Ajzen's model for planned behavior does indeed offer a workable scheme for the assessment of the willingness to change. Satisfactory relations between the variables from Ajzen's model and the willingness to change were found.

In previous studies, Abdelghany (2014) have studied mobile extension as a potential organizational change from the perspective of extension employees in the New Valley governorate, it came out that the respondents are ready for actualizing the mobile extension initiative, they have the adherent beliefs for this change, and their support to the change are greater than their resistance to it.
In the second study, Abdelghany (2015) have concentrated on farmers' behavioral intentions to use mobile extension in Assiut governorate, it turned out that there is a high (positive) intention to use mobile extension among the respondents, and their prospective behavior proceeds to utilize mobile extension service if it comes into existence.

By integrating the findings of the current study and the findings of the previous studies, the potential producers of extension services based on cell phones must catch this opportunity of the positive intentions of farmers, willingness of meddle level managers and the readiness of extension employees to begin performing this initiative practically taking into account the results of these studies.

\section{REFERENCES}

Abdel-Ghany, M.M.M. 2014. Readiness for change, change beliefs and resistance to change of extension personnel in the New Valley governorate about mobile extension, Annals of Agricultural Sciences, 59(2), 297303. 
Abdel-Ghany, M.M.M. 2015. Farmers' Behavioral Intentions to Use Mobile Extension in Assiut Governorate, Arab Univ. J. Agric. Sci., 23(2), 439-448.

Abdel-Ghany, M.M.M. and Diab, A.M. 2013. Reforming Agricultural extension in Egypt from the viewpoints of central level extension employees, Arab Univ. J. Agric. Sci., 21(2), 143-154.

Babu, S.C. and Joshi, P.K. 2015. Future of Agricultural Extension Reforms in Developing Countries: Lessons from India, e-Journal of Economics and Complexity, 1(1): 25-43. Retrieved Jan. 27, 2016 from:

http://www.cespi.it/E-journal/Babu\&Joshi-June2015.pdf

Bäckvall, L. and Englund, J. 2007. Middle Management: Constraints and Enablers for Middle Managers' Sense making and Sense giving Process. Master thesis, Jönköping International Business School, Jönköping University. Retrieved Jan. 30, 2016 from:

http://www.divaportal.org/smash/get/diva2:462 1/FULLTEXT01.pdf

Blackman, D., O’Flynn, J. and Ugyel, L. 2013. "A Diagnostic Tool for Assessing Organisational Readiness for Complex Change", paper presented to the Australian and New Zealand Academy of Management conference, Hobart, 4-6 December. Retrieved Nov. 15, 2015 from: https://www.anzsog.edu.au/media/upload/publi cation/131 Flynn-and-Ugyel-Diagnostic-ToolANZAM-2013.pdf

Bouckenooghe, D. and Devos, G. 2007. Psychological Change Climate as A Crucial Catalyst of Readiness for Change: A Dominance Analysis. Vlerick Leuven Gent Working Paper Series 2007/27. Retrieved Jan. 29, 2016 from:

https://www.researchgate.net/profile/Geert De vos/publication/23646775 Psychological chan ge climate as a crucial catalyst of readines s for change a dominance analysis/links/0c9 6052661d2945fef000000.pdf

Caye, J.M., Strack, R., Orlander, P., Kilmann, J., Espinosa, E.G., Francoeur, F. and P. Haen, P. 2010. Creating a New Deal for Middle Managers: Empowering a Neglected but Critical Group, The Boston Consulting Group, World Federation of People Management Associations. Retrieved Jan. 30, 2016 from: http://www.bcg.de/documents/file52425.pdf

Central Administration for Agricultural Extension 2011. Mobile agricultural extension, Egypt (in Arabic). Retrieved Feb. 13, 2015 from: http://caae-eg.com/index.php/askanswer/156..html
Cole, S. and Fernando, A. 2012. The value of advice: evidence from mobile phone-based agricultural extension, Harvard Business School Finance Working Paper No. 13-047. Retrieved Feb. 12, 2016 from:

http://www.dartmouth.edu/ neudc2012/docs/pa per 251.pdf

Fu, Xiaolan and Akter, S. (ND). The Impact of ICT on Agricultural Extension Services Delivery: Evidence from the Rural e-services Project in India. Department of International Development, University of Oxford, TMD Working Paper Series No. 046. Retrieved Feb. 12, 2016 from:

http://www3.qeh.ox.ac.uk/pdf/ptmd/SLPTMDWP-046.pdf

Helfrich, C.D., Blevins, D., Smith, J.L., Kelly, P.A., Hogan, T.P., Hagedorn, H., Dubbert, P.M. and Sales, A.E. 2011. Predicting implementation from organizational readiness for change: a study protocol, Implementation Science, 6: 76. Retrieved Jan. 28, 2016 from: http://www.implementationscience.com/content /pdf/1748-5908-6-76.pdf

Holt, D., Armenakis, A., Harris, S. and Field, H. 2007. Toward a comprehensive definition of readiness for change: a review of research and instrumentation, Research in Organizational Change and Development, 16: 289-336. Retrieved Feb. 12, 2016 from:

http://www.emeraldinsight.com/books.htm?cha pterid=1758902 \&show=pdf

Kuyvenhoven, R. and Buss, W.C. 2011. .A normative view of the role of middle management in the implementation of strategic change. Journal of Management \& Marketing Research, 8(1). Retrieved Jan. 30, 2016 from: http://www.aabri.com/manuscripts/11809.pdf

Mair, J. 2002. How much do Middle Managers Matter, Really? An Empirical Study on their Impact on Sustained Superior Performance. Research Division, IESE, University of Navarra, Spain, Research Paper No. 473. Retrieved Jan. 30, 2016 from: http://www.iese.edu/research/pdfs/DI-0473E.pdf

McKinney, R., McMahon, M. and Walsh, P. 2013. Danger in the Middle: Why Mid-Level Managers aren't Ready to Lead. Harvard Business School Publishing. Retrieved Jan. 30, 2016 from:

http://www.harvardbusiness.org/sites/default/fil es/PDF/17807 CL MiddleManagers White Pa per March2013.pdf 

Phones in Extension Services

Meera, S., Jhamtani, A. and Rao, D. 2004. Information and communication technology in agricultural development: a comparative analysis of three projects from India, Agricultural Research and Extension Network Paper No. 135. Retrieved Feb. 12, 2016 from:

http://www.odi.org.uk/sites/odi.org.uk/files/odiassets/publications-opinion-files/5186.pdf

Metselaar, Erwin E. 1997. Assessing the willingness to change: Construction and validation of the DINAMO. PhD thesis, University of Amsterdam, Retrieved Mar. 22, 2012 from: http://dare.ubvu.vu.nl/bitstream/handle/1871/15 590/283.pdf;jsessionid=61DAAEFEDA62C0232 7EA3E50B6DDE0B5? sequence $=1$

Ministry of Communications and Information Technology 2015. Information and Communications Technology Indicators Bulletin, Quarterly Issue, September 2015, Egypt. Retrieved Feb. 28, 2016 from:

http://www.mcit.gov.eg/Upcont/Documents/Pub lications 2322016000 EN-ICT-IndicatorsQuarterly-Bulletin-Q3.pdf

Mittal, S., Gandhi, S. and Tripathi, G. 2010. Socio-Economic Impact of Mobile Phones on Indian Agriculture, Indian Council for Research on International Economic Relations, Working Paper No. 246. Retrieved Jan. 29, 2016 from: http://www.eaber.org/sites/default/files/docume nts/Socioeconomic\%20Impact\%20of\%20Mobil e\%20Phones\%200n\%20Indian\%20Agriculture. pdf

Petrou, P. and Demerouti, E. 2015. Job Crafting in Changing Organizations: Antecedents and Implications for Exhaustion and Performance, Journal of Occupational Health Psychology, 20(4): 470-480. Retrieved Jan. 27, 2016 from: http://www.wilmarschaufeli.nl/publications/Scha ufeli/445.pdf
Ryan, N., Williams, T., Charles, M. and Waterhouse, J. 2008. Top-down organizational change initiatives, Emerald Group Publishing Limited. Retrieved Jan. 30, 2016 from: http://www.emeraldgrouppublishing.com/learnin $\mathrm{g} /$ management thinking/articles/pdf/top down. pdf

Susanto, A.B. 2008. Organizational Readiness for Change: A Case Study on Change Readiness in a Manufacturing Company in Indonesia. International Journal of Management Perspectives, 2(1): 50-62. Retrieved Nov. 15, 2015 from: http://www.ibts.org/spring2008/A B Susanto.p df

The World Bank 2011. ICT in agriculture, connecting smallholders to knowledge, networks, and institutions, Report Number 64605, Washington, DC. Retrieved Feb. 12, 2016 from: http://www.ictinagriculture.org/sites/ictinagricult ure.org/files/final book ict agriculture.pdf

Vodafone Egypt 2011. Vodafone launches agricultural guidance services via mobile. Retrieved Feb. 13, 2015 from:

http://www.vodafone.com.eg/vodafoneportalWe

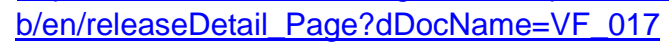
$\underline{939}$

Vos, Janou 2006. The Role of Personality and Emotions in Employee Resistance to Change. Master thesis, Faculty of the Social Sciences, Erasmus University Rotterdam.

Weiner, B.J. 2009. A theory of organizational readiness for change. Implementation Science, 4: 67. Retrieved Nov. 15, 2015 from: http://www.implementationscience.com/content /pdf/1748-5908-4-67.pdf 